\section{Spatial optimization of Jatropha based electricity value chains including the effect of emissions from land} use change

\section{Joana Almeida ${ }^{ \pm}$}

KU Leuven, Division of Forest, Nature and Landscape, Celestijnenlaan 200E-2411, 3001 Leuven, Belgium. joana.almeida@kuleuven.be

Annelies De Meyer ${ }^{ \pm}$

KU Leuven, Division of Forest, Nature and Landscape, Celestijnenlaan 200E-2411, 3001 Leuven, Belgium. annelies.demeyer@kuleuven.be

\section{Dirk Cattrysse}

KU Leuven, Centre for Industrial Management / Traffic \& Infrastructure, Celestijnenlaan 300-2422, 3001 Leuven,Belgium.dirk.cattrysse@kuleuven.be

Jos Van Orshoven

KU Leuven, Division of Forest, Nature and Landscape, Celestijnenlaan 200E-2411, 3001 Leuven, Belgium. jos.vanorshoven@kuleuven.be

Wouter MJ Achten

Université libre de Bruxelles (ULB), Institute for Environmental Management and Land Use Planning (IGEAT), Avenue F. D. Roosevelt 50 - C.P. 130/02, 1050 Brussels, Belgium.wouter.achten@ulb.ac.be

Bart Muys*

KU Leuven, Division of Forest, Nature and Landscape, Celestijnenlaan 200E-2411, 3001 Leuven, Belgium. bart.muys@kuleuven.be

\footnotetext{
${ }^{ \pm}$Authors contributed equally to this work.

* Corresponding author.
} 
Jatropha was identified as a potential feedstock to satisfy off-grid and on-grid energy solutions. However, the potential has been questioned due to agronomic frustrations, the lack of an organized value chain and heavy criticism on biofuels due to emissions triggered by land use change (LUC). To contribute to the realistic integration of Jatropha in rural development, this article proposes a modeling approach to probe the feasibility of Jatropha-based electrification in rural Africa and the layout of such a value chain. A multi-component modeling setup is presented, featuring a life cycle inventory, spatial modeling and the optimization model, OPTIMASS. In this modeling setup, OPTIMASS is parameterized with data regarding the global warming potential and the potential location of each operation in the value chain including cultivation sites and related LUC emissions. This enables OPTIMASS to spatially design the Jatropha-based on-grid and off-grid electrification value chain (i.e. cultivation, transport and storage, biofuel production and electricity generation) in Southern Mali with minimal GWP to reach 10\% substitution of fossil fuels for Jatropha in electricity production for a current and two future electricity demand scenarios. Analysis of the optimization results demonstrates that emissions from transporting the oil are lower than LUC emissions per harvestable seed of other sites. Finally, it can be said that harnessing the entirety of the Jatropha value chain is crucial to make it GWP competitive relative to fossil fuels in which the location of plantations is crucial to attain low LUC-related emissions and viable yields.

\section{Keywords}




\section{Introduction}

Mali's current low level of electrification and its population's increasing demand for electricity has motivated efforts to diversify electrical energy sources and to decentralize electricity generation as mentioned by the national policy for the development of renewable energy [1]. This policy has set the goals for renewable energies to reach $10 \%$ of the energy mix by 2015 [1]. Furthermore, it aims at stimulating the development of the biofuel sector, particularly to boost local energy generation and to promote rural electrification.

Jatropha was identified and encouraged as a potential feedstock to satisfy off-grid and on-grid energy solutions able to ensure energy self-sufficiency and provide additional revenues to small farmers [2-4]. This small tree yields seed, of which the oil can be extracted for direct use or conversion to biodiesel. Several studies indicate that Jatropha's promise of being a sustainable fuel can be fulfilled in small scale systems meeting the energy needs of local communities in rural areas, rather than in massive production for large scale overseas consumption $[5,6]$. Motivation has, however, dwindled due to widespread frustration among small and large Jatropha farmers, investors and targeted communities, who faced both agronomical challenges and the lack of a value chain befitting their needs downstream of cultivation [7-10].

In the midst of the boom and bust trajectory of Jatropha, biofuels became the target of heavy criticism due to estimates that greenhouse gas (GHG) emissions caused by converting land into bioenergy crops may surpass the benefit of replacing fossil fuels [11, 12]. The magnitude of emissions from direct land use change (LUC) depends on local site conditions, on the previous land use and on the fate of $\mathrm{C}$ stocks beyond the LUC event. For this reason, the choice of land onto which to implement bioenergy plantations becomes paramount to ensure that they meet their purported goal of mitigating climate change.

At a strategic decision level, optimization of value chains can help to define the long-term geographical layout of biomass production and conversion plants, and to select the optimal technologies for biomass conversion to bioenergy complying with certain goals [13-15]. In order to optimize for minimal environmental impact, it is crucial to identify and quantify the impact at all stages in the chain, so that the optimization models are fully parameterized with environmental impact information for each operation. This is, however, often not the case, as most existing optimization models focus on individual parts of the value chain [16]. This can be solved by integrating life cycle thinking in optimization, whereby the value chain is seen as a system with its own life cycle inventory (LCI) and subject to a life cycle impact assessment (LCIA). Moreover, as value chains are often spread over a geographical extent, the integration of spatial analysis can support the definition of the optimization problem, the parameterization and visualization of value chain layouts. The combination of mathematical optimization models, LCIA and spatial analysis has been previously shown suitable to support strategic decision questions on bioenergy value chains [17-20].

This paper aims to present a methodology to combine life cycle assessment (LCA) metrics for climate change, the Global Warming Potential (GWP), with decision optimization. The decision environment is implemented in a multi-component modeling setup, featuring a life cycle inventory, spatial modeling and the mixed integer linear programming (MILP) model, OPTIMASS [21]. Secondly, this paper has the objective to apply this methodology to define the optimal spatial land allocation and to optimize the value chain setup in terms of lowest GWP for on-grid and off-grid electrification with Jatropha-based biofuels in Southern Mali considering the spatial configuration of the value chain (i.e. location and dimension of production, cultivation, processing 
and use sites). For this purpose, all relevant inputs and emissions of the Jatropha-to-electricity value chain must be defined, including LUC emissions. To our knowledge, LCA and optimization have already been combined to create spatially optimized supply chains in the sense of identifying locations for conversion plants, transport routes, etc. [22-25], but not to identify the land where it would be possible or the best to cultivate the crop. So, it can be stated that this spatial explicit optimization method, including the spatial allocation of land, for improving energy security in developing countries is novel. In addition, the incorporation of a dedicated LUC emissions assessment makes it one of the most complete GWP parameterizations of a bioenergy value chain optimization model so far. Based on these results, this paper aims to generalize key findings in relation to the implementation of Jatropha as a potential feedstock to satisfy off-grid and on-grid energy solutions.

\section{Methods}

\subsection{Study area}

The study area is the south of Mali, comprising the provinces of Kayes, Koulikoro, Sikasso, Ségou and Mopti, and the Bamako capital district (total extent $427266.7 \mathrm{~km}^{2}$ ). Mali is a landlocked country in west Africa, with nearly 16 million inhabitants, the majority of which live in this Southern region (figure 1) [26].
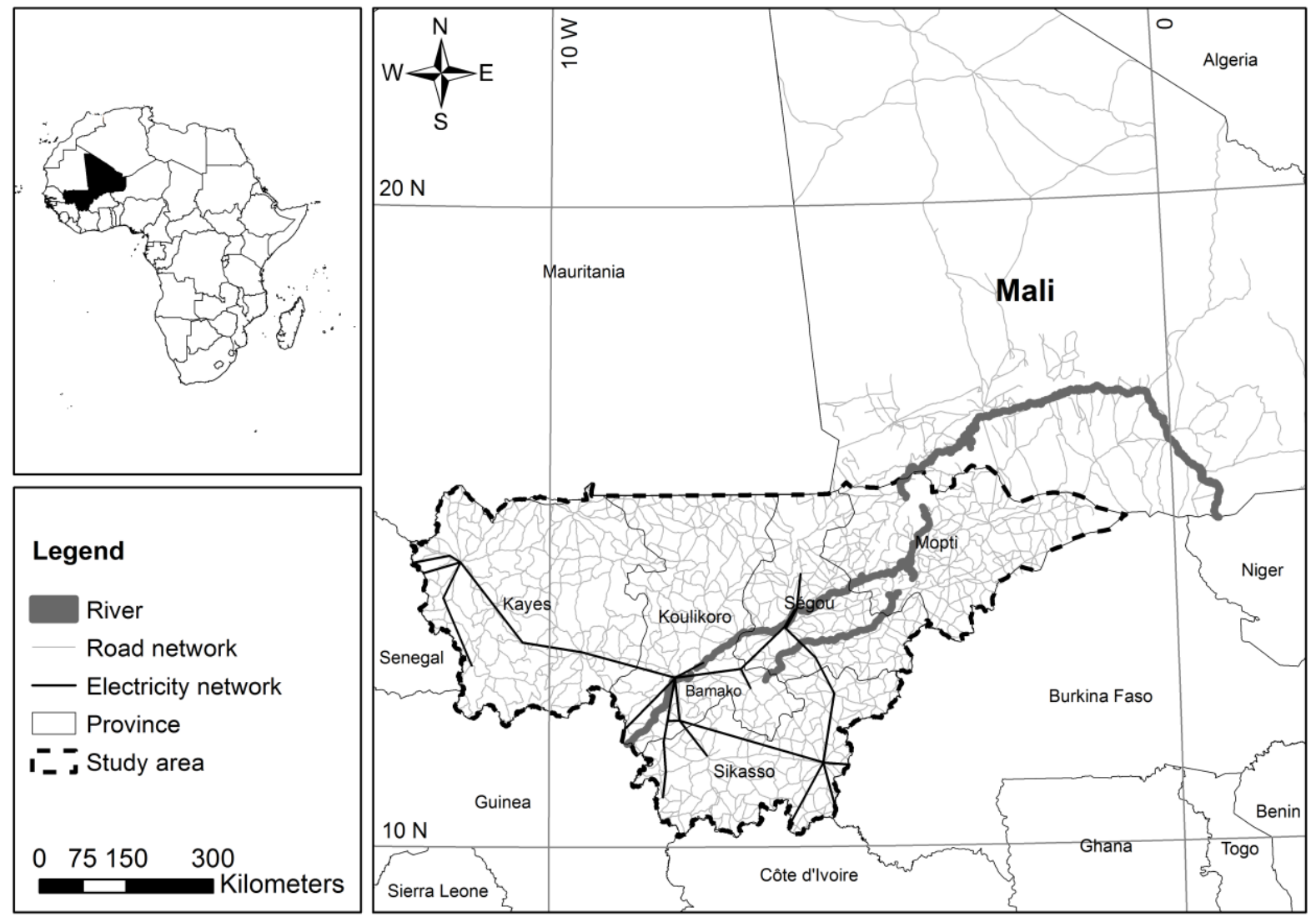

Figure 1 - Location of the study area, Malian infrastructure of relevance to this study (roads, thermal power plants and electricity transmission network) and location of water bodies and nature reserves. 
According to the latest statistics, only $27.1 \%$ of the country's population has access to electricity (14\% in rural areas), and the annual pro capita electricity consumption is $108.5 \mathrm{kWh}$, one of the lowest in the world [1, 26, 27]. Mali's electricity mix is partially dependent on imports, with $40 \%$ coming from fossil fuels and the remaining $60 \%$ from national hydropower [28]. The low electrification rate, particularly in rural areas, and the dependence of external fuels has motivated a national energy policy targeting a further penetration of $10 \%$ renewable sources in the country's fossil energy based electricity production. Renewables, more particularly Jatropha-based biofuels, are also seen as one of the solutions for off-grid electricity generation in rural areas, meant to increase the rural electrification rate to $55 \%$ by 2015 [1].

Predicted Jatropha plantation yields in the study area can range from a few kilogram dry seed per hectare in the North to nearly $3 \mathrm{t} \mathrm{ha}^{-1}$ in the southernmost tip of the study area [29]. This massive yield range is mainly related to climatic conditions since the northern part of the study area borders the dry and less productive Sahara region. Indeed, suitable zones reflecting high yields of Jatropha are characterized as tropical and hot temperate areas with sufficient precipitation and absence of frost [29]. Also, soil and topographic conditions can interfere [29, 30].

\subsection{Optimization procedure}

The mixed integer linear programming (MILP) model, OPTIMASS, is designed to support strategic and tactical decisions in all types of biomass-based value chains aiming at maximal net energy output, maximal revenue or minimal global warming potential [21]. So, OPTIMASS is able to define the optimal location, technology and capacity of operations and operation facilities simultaneously with the optimal allocation of biomass(-based) materials from the biomass production site to operation facilities and between operation facilities [21]. To enable its application to all types of biomass-based value chains, OPTIMASS is based on a generic cradle-to-gate analysis of the biomass value chain which supports the representation of all types of biomass-based value chains in a similar manner (figure 2) [21]. The MILP model incorporates constraints to regulate the sequence of operations (figure 2), to ensure the mass balance in the flow of products through operations, between operations and between locations and to guarantee the meeting of a pre-defined energy and/or by-product demand [21]. Different from existing optimization models is that OPTIMASS considers changes in biomass characteristics due to handling operations and includes the re-injection of by-products from the conversion process in the value chain supporting a more realistic approach of the value chain [21]. A detailed description of the MILP model is given in [21].

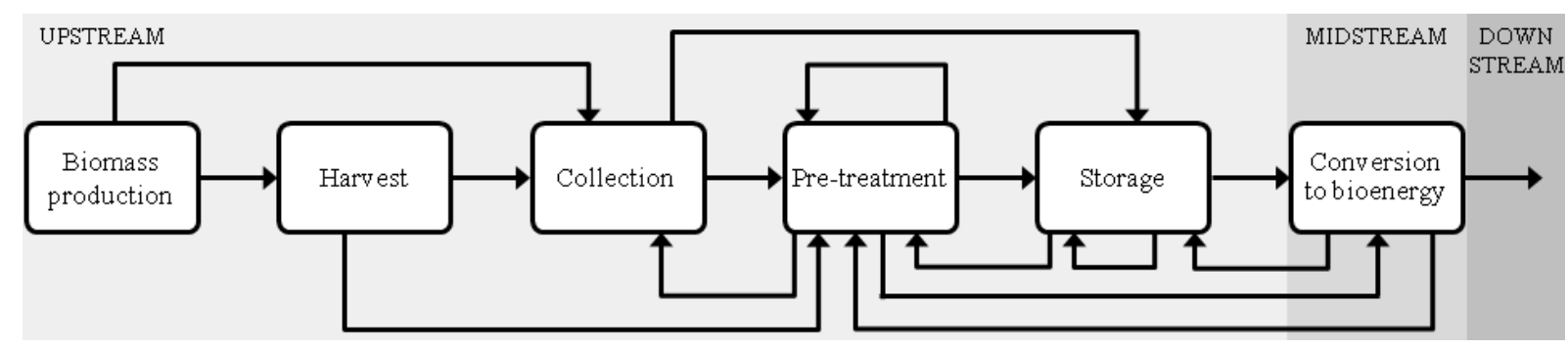

Figure 2 - High level process model of the biomass-based value chain. The boxes represent the 6 key operation types distinguished in the generic cradle-to-gate analysis while the arrows indicate the possible material flows between the key operation types. 
In this paper, OPTIMASS has been used to minimize the GWP of the Jatropha based value chain in the south of Mali (Section 2.1), considering the scenarios as described in section 2.5. This implies that OPTIMASS determines the optimal sites for Jatropha cultivation and the optimal location, technology and capacity of operation and conversion facilities within the study area to result in the Jatropha based value chain with the minimal GWP. Consideration of the spatial differences in yield and land use change emissions allows for OPTIMASS to select the cultivation areas with the best emission-yield combinations in relation with the location, type and capacity of all other operations required in the value chain.

OPTIMASS has been developed with low input high diversity biomass systems in mind. Therefore, no "cost" has been included in the objective function related to the cultivation or production of biomass. In this paper, the objective function, included in OPTIMASS, has been extended to include emissions from the preparation of the field, irrigation, fertilization and application of pesticides related to the cultivation of Jatropha at the optimal cultivation areas. Also, an equation has been added to the objective function to determine the emissions caused by converting land into Jatropha plantations (LUC) at those sites. Additionally, this paper contributes to the OPTIMASS model by developing a parameterization specific for Jatropha, which also means we extended the scope to the land use effect on biomass and soil carbon.

\subsection{Parameters required in OPTIMASS}

\subsubsection{Potential Jatropha-based value chains}

The definition of potential value chains for Jatropha-based electricity generation is based on field information collected from Jatropha projects in Mali, as well as literature [31-33]. The studied value chain(s) can be divided in three main phases: i.e. cultivation, biofuel production and electricity generation (figure 2).

The operations included in cultivation (figure 3 (a)) are the preparation of the field, irrigation, fertilization and application of pesticides. Periodical weeding and harvesting also occur, but no related emissions are included as they are done manually. The fruits are then processed by electrical dehulling and the seed is dehusked with an electrical dehusker and air dried (figure 3 (b)). Mechanical presses extract $16 \mathrm{~g}$ of oil per $100 \mathrm{~g}$ of seeds [31]. Biodiesel is not produced because it has the same energy yield and tailpipe emissions than oil [34], not compensating for the added environmental burden of transesterification [33]. So, both vapor turbine connected to the grid as well as a stationary diesel engine are assumed to run on untreated plant oil (figure 3 (c)). It was considered that with $1 \mathrm{~kg}$ of oil large power plants generate $4.5 \mathrm{kWh}$ electricity, while smaller, less-efficient stand-alone generators (off-grid) generate $3.5 \mathrm{kWh}[31,33]$. Modifications to the thermal power plants so as to accommodate biofuels and distribution losses are excluded from this analysis, as it is assumed that all existing thermal power plants in Mali are able to use liquid biofuels to a maximum blend of $10 \%$. Storage tanks for oil are also foreseen.

Parameters independent of spatial data are those intrinsic to the inputs and operations of the value chain that do not change as a function of their location. They are sequence of operations and their inter-relations (figure 3 ) and the efficiencies of oil extraction and electricity generation. Emission factors of producing a given unit of system inputs, such as the GHG emissions of producing $1 \mathrm{~kg}$ of fertilizers and pesticides or one unit of stationary equipment and of transporting $1 \mathrm{t}$ of oil for $1 \mathrm{~km}$, also fit in this category: although input amounts ultimately 
depend on spatial parameters, these emission factors do not. The foreground data on system layout and quantification of the value chain of Jatropha-based electricity generation are specific for Malian practice, based on field information collected from Jatropha projects in Mali, as well as literature [31-33]. The input quantification to all operations is given in the Supplementary Material.

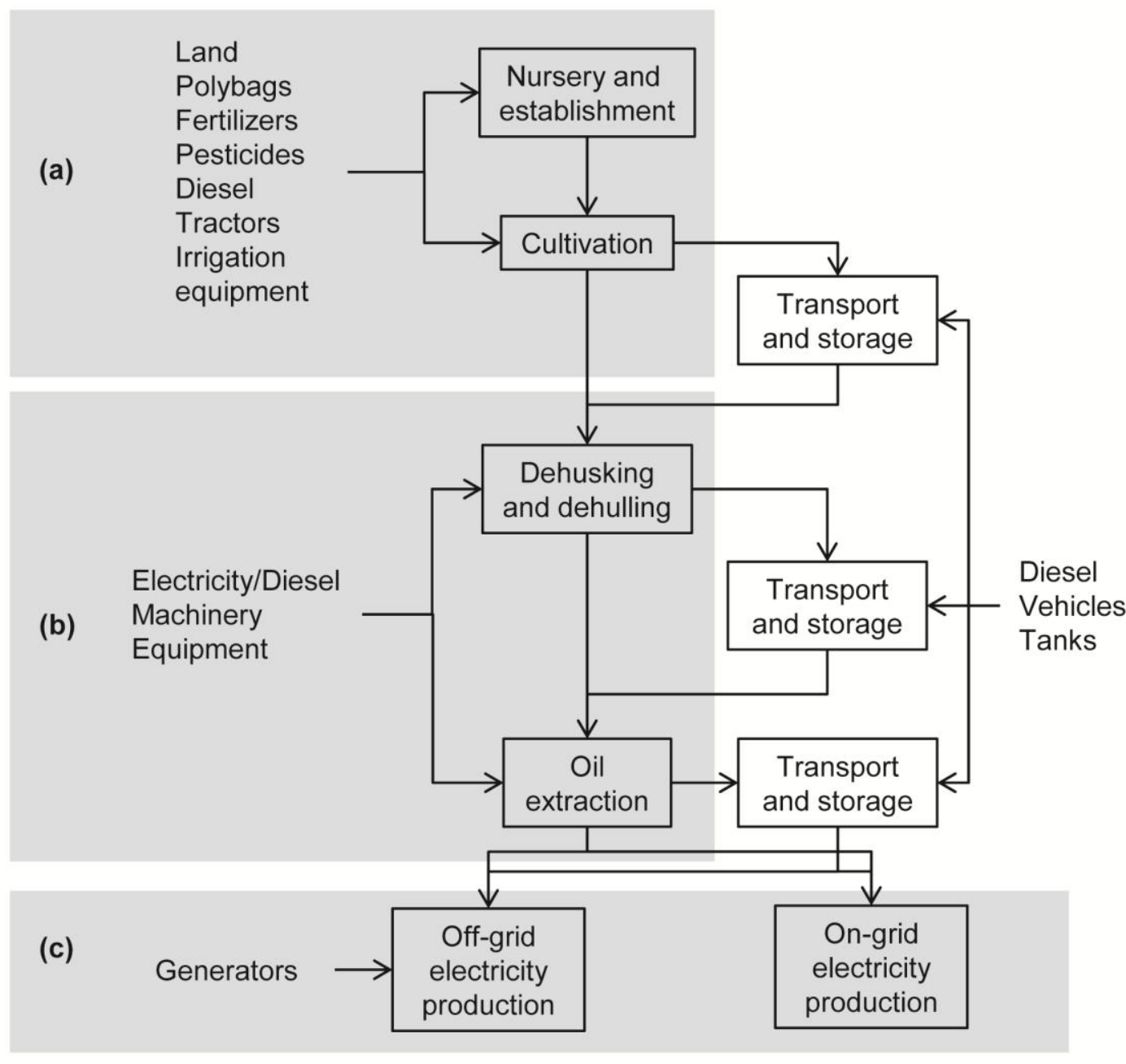

Figure 3 - Schematic value chain of off-grid and on-grid Jatropha-based electricity production, corresponding to the system boundaries of the LCIA. The grey zones define the three main operations: (a) - Cultivation, (b) Biofuel production, (c) - Electricity generation. The boxes indicate the operation processes in the value chain. The remaining elements are the inputs to the value chain whose emissions of provision and use are included in the LCIA. The arrows represent fluxes of materials and energy connecting the inputs with the operation processes and between operation processes.

\subsubsection{Location-dependent parameters}

The location-dependent inputs (operation sites and transport links - figure 4) are calculated in a pre-processing stage using ArcGIS® software (ESRI, USA), where the intervening processes and their parameters are georeferenced. These parameters are all possible operation sites and transportation distances, seed yield and land use change emissions. All potential operation locations and the necessary geodatasets to estimate spatial-dependent parameters are given in the Supplementary Material. 


\section{Legend}

* Potential cultivation cell

Potential storage location

Potential local generator

Potential thermal power plant

- $69-100 \mathrm{MWh}$ per year

- $101-500 \mathrm{MWh}$ per year

- 501-1500 MWh per year

- $1501-3500 \mathrm{MWh}$ per year

3501-6794 MWh per year

Temporary flooded area

a

$\square$ Study area

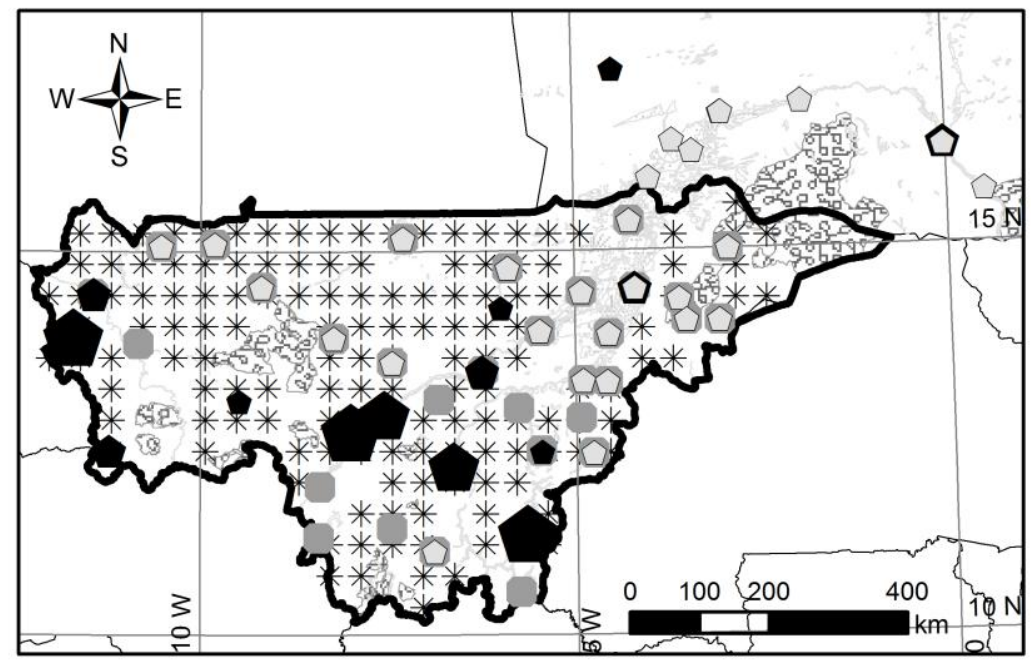

191

Figure 4 - Potential operation sites.

It was assumed that potential sites of biofuel production plants and seed and biofuel storage facilities are located in the vicinity of main towns or main road nodes to ensure easy access and delivery of the inputs to these facilities as well as to connect the final product to the market. The potential sites to implement stand-alone generators are the cercles that are not located in the vicinity (more than $10 \mathrm{~km}$ distance) of the transmission network. OPTIMASS determines if dehusking and dehulling occurs at the cultivation site, the biofuel production site, the storage site or the electricity generation site, and assumes that oil is produced in independent biofuel production sites or at the electricity generation site.

The transportation distances of all possible paths between two potential operation sites are determined on a layer of the existing Malian road network and stored in the database. Three possible transportation modes are considered: lorry, motorcycle and tractor.

Background data on the production and use of the materials and fuels used by the value chain (fertilizers, pesticides, diesel, electricity, transport, machinery and stationary equipment) are extracted from the ecoinvent ${ }^{\circledR}$ v3 database (Centre for Life Cycle Inventories, Switzerland). The emissions caused by these background processes were estimated with ReCiPe's GWP midpoint hierarchical [35] in SimaPro ${ }^{\circledR}$ (PRé, the Netherlands); which is in practice the IPCC $2007100 \mathrm{yr}$ GWP. Direct $\mathrm{N}_{2} \mathrm{O}$ emissions to air from fertilizer application [36] were also included. Tailpipe emissions are assumed to be the same in generators and thermoelectric turbines and were extracted from the GREET 2013 model [37]. These emissions exclude biogenic carbon-based GHGs.

Potential cultivation sites were parameterized with an average yield [29] (figure A1) and an average LUC emission (figure 5). The study area is divided in a grid of $45 \times 45 \mathrm{~km}\left(2025 \mathrm{~km}^{2}\right)$ cells, the spatial resolution being limited by computational power. The average yield and average LUC emission are attributed to the centre of the cell for the purpose of calculating transport distances. The total LUC emission of a cell (LUC $\left.\mathrm{E}_{j}\right)$ is the $\mathrm{CO}_{2}$ released upon the disturbance caused by removing part of its land cover to establish Jatropha, and is calculated as the sum of the biomass carbon loss and the soil carbon loss amortized for a rotation period of 20 years. The estimation of land use change emissions is described in detail in the supplementary material. 
The lowest possible LUC emission resulting from Jatropha establishment in a potential cultivation area is $0.7 \mathrm{t}$ $\mathrm{ha}^{-1} \mathrm{yr}^{-1}$ of $\mathrm{CO}_{2}$, while it can reach up to $19.1 \mathrm{t} \mathrm{ha}^{-1} \mathrm{yr}^{-1}$ of $\mathrm{CO}_{2}$ in less favorable parts of the country (figure 5 - a). On average, cells have a LUC emission of $3.7( \pm 2.9) \mathrm{t} \mathrm{ha}^{-1} \mathrm{yr}^{-1}$ of $\mathrm{CO}_{2}$. The $\mathrm{CO}_{2}$ intensity per seed yield ranges from 0.7 to $96.2 \mathrm{t} \mathrm{t}^{-1}$ seed $\mathrm{yr}^{-1}$ (figure 5 - b). This range is mainly due to the very variable Jatropha yield and the very variable carbon debt. A combination of a low LUC emission and high yield would keep the CO2 intensity low while the combination of a high LUC emission and a low yield would increase the CO2 intensity. Given the range in the LUC emissions, and the range of yields, the range of carbon intensities will be boosted. The fraction of SOC lost after one rotation of Jatropha ranges from 6 to $37 \%$, resulting in an emission of 0.2 to $3.1 \mathrm{t} \mathrm{ha}^{-1} \mathrm{yr}^{-1}$ of $\mathrm{CO}_{2}$. The loss of SOC under Jatropha is for the whole Southern Mali on average $24.5( \pm 10.8) \mathrm{tha}^{-1} \mathrm{of} \mathrm{CO}_{2}(1.2$ $( \pm 0.5) \mathrm{tha}^{-1} \mathrm{yr}^{-1}$ of $\mathrm{CO}_{2}$ ). Emitted $\mathrm{CO}_{2}$ upon biomass clearing can range from 0.1 to $5.1 \mathrm{t} \mathrm{ha}^{-1} \mathrm{yr}^{-1}$.

\begin{tabular}{|c|c|}
\hline \multicolumn{2}{|l|}{ Legend } \\
\hline $\begin{array}{l}\text { UC-relate } \\
\text { ton } \mathrm{CO} 2 \mathrm{p}\end{array}$ & ha per \\
\hline - $0-2$ & \\
\hline ㅇ $3-4$ & \\
\hline - 4-6 & \\
\hline $6-10$ & \\
\hline $\begin{array}{r}10-2 \\
\text { Study }\end{array}$ & \\
\hline 075150 & 300 \\
\hline
\end{tabular}

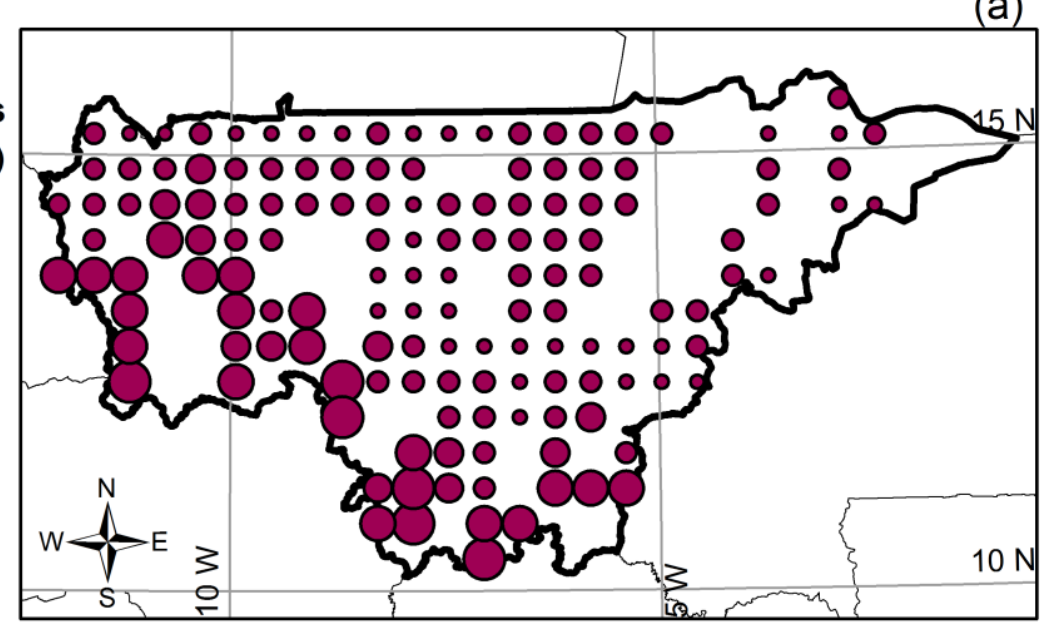

\section{Legend}

LUC-related emissions (ton $\mathrm{CO} 2$ per ton seed)

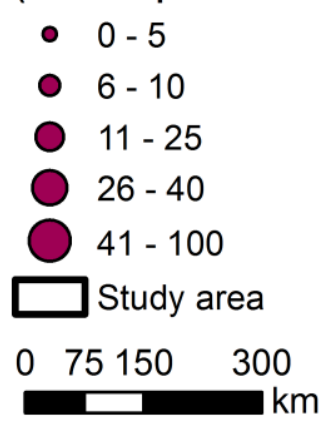

Figure 5 - Emissions from land use change amortized over a period of 20 years in function of area (a) and of the yields of Jatropha (b) in each potential cultivation area in Southern Mali. The diameter of the rings represents the relative amount of LUC induced $\mathrm{CO}_{2}$ emitted per hectare (a) or tonne of seed harvestable in each cell (b). 
Land has been a central topic in the discussion on Jatropha's sustainability (e.g. preferential occupation of degraded lands to limit LUC emissions and avoid conflicts with food production) [38, 39]. OPTIMASS does not determine where Jatropha cultivation occurs within the cell. This implies that any land cover within a cell can potentially be replaced with Jatropha plantations, with the exception of urban areas, water bodies and protected areas (such as natural parks and nature reserves). By considering any land cover as replaceable, OPTIMASS can freely deliberate on the LUC emissions and allocate cultivation to the lowest possible emission regardless of the land cover replaced. This allows OPTIMASS to select the cultivation areas with the best emission-yield combinations in relation with the location, type and capacity of all other operations required in the value chain. In order to verify which land covers are displaced by Jatropha plantations, the selected cultivation cells in the optimal value chains were combined with a land cover map [40].

\subsection{Electricity demand scenarios}

OPTIMASS can be used as a pull model, which means that the optimization is triggered by a pre-set energy demand, rather than by the biomass value. As such, this exercise tests three electricity demand scenarios that satisfy goals set by Malian bioenergy policy [1]. In each scenario, the demand corresponds to an annual amount of electrical energy to be satisfied by Jatropha-based biofuels, calculated according to equation 1.

$$
\text { Annual demand }=\text { Demand per user } \times \text { Served population } \times 40 \% \times 10 \%
$$

The three scenarios differ in the size of the population to be served, the value setting (on-grid versus rural offgrid) and per user demand to be served by Jatropha-based electrification (table 1). All three scenarios correspond to $10 \%$ of the fossil-based electricity consumed by a certain population group to be supplied by Jatropha biofuels (i.e. $10 \%$ in eq. 1), while it is assumed that hydroelectric stations remain the source of $60 \%$ of generated electricity (i.e. $40 \%$ in eq. 1 ).

In the reference scenario (Scenario 1), the population already connected to the electrification grid is served. In this scenario the current demand was defined according to the most recent national statistics of 2012 [26]. For the two subsequent demand levels, we project onto the year 2020, taking into account an increase in the rural electrification rate to $55 \%$ [1]. The second scenario satisfies $10 \%$ substitution of fossil-based electricity required by rural off-grid population in 2020, while the third scenario satisfies on-grid and rural off-grid population in 2020 (table 1). The projected population increase [41] and the expected fast annual electricity demand rise of $10 \%$ are foreseen in scenarios 2 and 3 [1] (table 1).

The value setting (on-grid versus rural off-grid) implies different configurations for the final stage of the value chain. While in Scenario 1 all biofuel is fired in existing thermal power plants, in Scenario 2 it is used in diesel engines to be installed in areas not connected to the electricity distribution network, and in Scenario 3 it can be used in existing thermal power plants and additional off-grid generators. How much energy is generated in each location and with what technology in function of data such as population size, transportation distances, proximity to electricity network and capacity of the thermal power plants? 
Table 1 - Description of the three electrification scenarios and their electricity demand fed into OPTIMASS in which the projection onto 2020 is based on the data available in [1,41].

\begin{tabular}{llll}
\hline & $\begin{array}{l}\text { Scenario 1 } \\
\text { (current) }\end{array}$ & $\begin{array}{l}\text { Scenario 2 } \\
\text { (future off-grid) }\end{array}$ & $\begin{array}{l}\text { Scenario 3 } \\
\text { (future off- and on-grid) }\end{array}$ \\
\hline Year & 2012 & 2020 & 2020 \\
$\begin{array}{l}\text { Substitution of fossil energy based } \\
\text { electricity }\end{array}$ & $10 \%$ & $10 \%$ & $10 \%$ \\
Rural electrification & $14.21 \%$ & $55 \%$ & $55 \%$ \\
Served population (Million) & 4.3 & 6.8 & 10.2 \\
Target population (supply) setting & On-grid & Rural off-grid & On-grid and rural off-grid \\
Annual demand per user $(\mathrm{kWh})$ & 108.52 & 232.63 & 232.63 \\
\hline Total annual demand $(\mathrm{GWh})$ & 18.6 & 63.1 & 95.3 \\
\hline
\end{tabular}

\subsection{Sensitivity analysis}

The sensitivity of the GWP and the geographical layout of the optimal value chain to LUC emissions and to land availability are tested. For this purpose, OPTIMASS is run with two extra setups: (i) with a limit of 5000 ha to be occupied in each selected cultivation area; and (ii) without taking into account LUC emissions. In these simulations, the remaining parameters remained the same.

\section{Results}

\subsection{Global warming potential}

The total GWP of the value chain predictably increases with larger demands, thus being lowest in Scenario 1 (22.7 $\mathrm{Gg}$ of $\mathrm{CO}_{2}$ eq) and highest in Scenario 3 (138 $\left.\mathrm{Gg}_{\text {of }} \mathrm{CO}_{2} \mathrm{eq}\right)$. When evaluated in function of generated electricity, Scenario 2 (rural electrification) has the highest GWP impact: $1.56 \mathrm{~kg} \mathrm{kWh}^{-1}$ of $\mathrm{CO}_{2}$ eq, while scenario 1 is the most efficient: $1.22 \mathrm{~kg} \mathrm{kWh}^{-1}$ of $\mathrm{CO}_{2}$ eq (figure 6).

In all scenarios, the largest sources of GHG emissions are LUC (78\%) and cultivation (19\%) (figure 6). Operations downstream from cultivation are only responsible for $3 \%$ of emissions. This includes transport, emissions from energy use for dehusking, dehulling and oil extraction, the production and use of generators (in scenarios 2 and 3) and tailpipe emissions from electricity production.

\subsection{Optimal value chain}

The same cultivation cell and storage site, located in the province of Sikasso, has been selected by OPTIMASS as optimal for all scenarios (figure 7 - left column, table 2). The dry seed yield in this cell is $1.48 \mathrm{t} \mathrm{ha}^{-1}$, which is above the median of the Jatropha yield range in all cells $\left(0.031\right.$ to $\left.2.500 \mathrm{t} \mathrm{ha}^{-1}\right)$. Given the productivity within this particular cell, this requires the occupation of 174,757 and $1067 \mathrm{~km}^{2}$ with Jatropha plantations in the respective scenarios. This corresponds to 9 and $53 \%$ of the total cell area. The $\mathrm{CO}_{2}$ emission from LUC in this area is $20.3 \mathrm{t}$ $\mathrm{ha}^{-1}$ or $0.7 \mathrm{t} \mathrm{t}^{-1}$ seed $\mathrm{yr}^{-1}$. The lost $\mathrm{CO}_{2}$ due to the removed biomass is $0.7 \mathrm{t} \mathrm{ha}^{-1} \mathrm{yr}^{-1}$ and $6 \%$ of the initial SOC content is released, which amounts to $0.3 \mathrm{t} \mathrm{ha}^{-1} \mathrm{yr}^{-1}$ of $\mathrm{CO}_{2}$. 


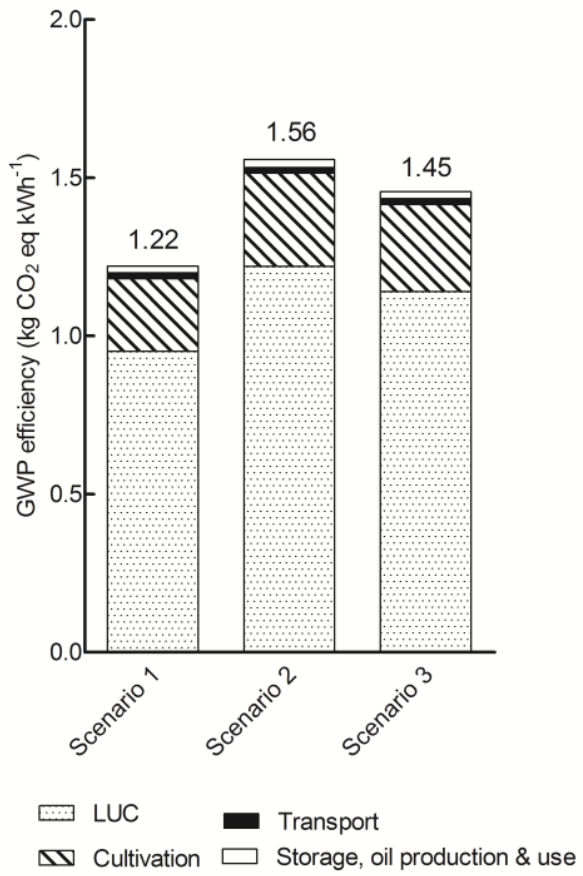

Figure 6 - Contribution of the stages in the value chain to the GWP efficiency of each scenario. The stacked bars represent broad value chain stages.

Table 2 - Summary of the characteristics of the selected cultivation cell within the Jatropha based value chains optimized according to the 3 scenarios.

\begin{tabular}{l|l|l|l}
\hline & $\begin{array}{l}\text { Scenario 1 } \\
\text { (current) }\end{array}$ & $\begin{array}{l}\text { Scenario 2 } \\
\text { (future off-grid) }\end{array}$ & $\begin{array}{l}\text { Scenario 3 } \\
\text { (future off- and on-grid) }\end{array}$ \\
\hline Total annual demand (GWh) & 18.6 & 63.1 & 95.3 \\
\hline Yield ( $\left.\mathrm{t} \mathrm{ha}^{-1}\right)$ & 1.48 & 1.48 & 1.48 \\
$\mathrm{CO}_{2}$ emission from LUC $\left(\mathrm{t} \mathrm{ha}^{-1}\right)$ & 20.3 & 20.3 & 20.3 \\
$\mathrm{CO}_{2}$ emission from LUC $\left(\mathrm{t} \mathrm{t}^{-1} \mathrm{seed} \mathrm{yr}^{-1}\right)$ & 0.7 & 0.7 & 0.7 \\
$\mathrm{Amount}^{-1}$ of dry seed needed $(\mathrm{kt})$ & 26 & 112 & 158 \\
Required area for Jatropha $\left(\mathrm{km}^{2}\right)$ & 174 & 757 & 1067 \\
\hline
\end{tabular}

The fruit is dehulled and the seed is dehusked on site and transported to the transformation site, where the seed dries and the oil is extracted. In the baseline and rural electrification scenarios ( 1 and 2, respectively) the GWP of transport is minimized by producing electricity primarily in the vicinity of storage. In Scenario 1, Jatropha oil is used in the four power plants closer to the cultivation site, coinciding with the power plants with higher capacity (figure 7, left column - a). In Scenario 2, the nearest off-grid cercle has generators installed (figure 7 , left column - b), with a respective capacity of $63 \mathrm{GWh} \mathrm{yr}^{-1}$. The electricity demand in Scenario 3 requires more electricity generation sites: 16 in total (figure 7, left column - c). In this scenario, thermal power plants outside the study area also receive Jatropha oil, and in addition, the same cercle as in Scenario 2 is electrified. It can be observed that the higher the demand, the farther the oil travels due to the limitations in the capacity of the thermal power plants. The fact that Jatropha is not necessarily cultivated near the use points indicates that the emissions from transporting the oil are lower than the LUC emissions per harvestable seed of other sites. 
Baseline

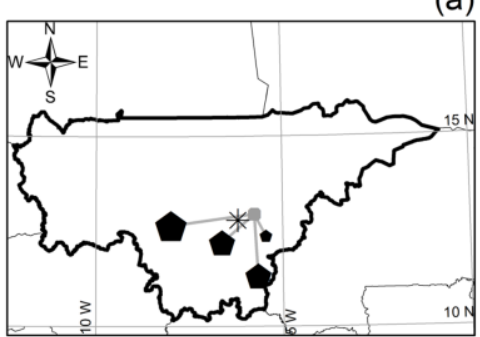

(b)

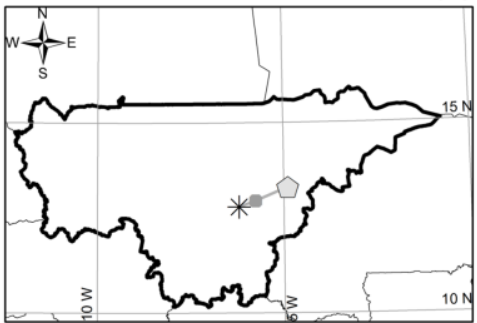

(c)

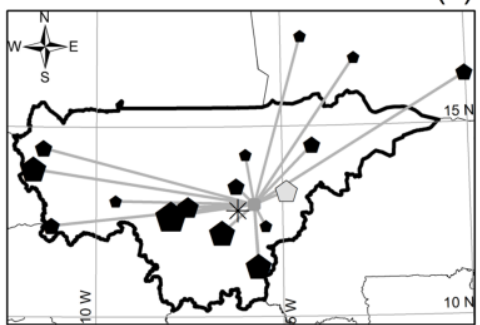

Legend

* Selected cultivation cell

- Selected storage location
5000 ha constraint

(a)

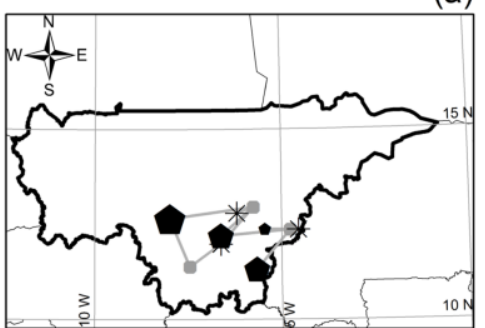

(b)

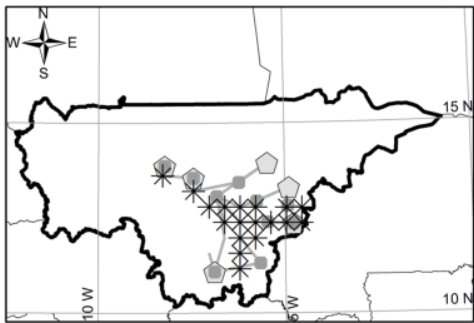

(c)

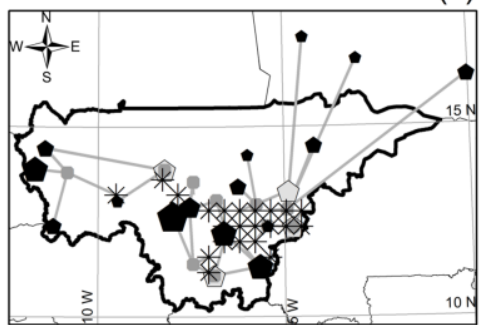

3

Selected local generator

Selected power plant
Without LUC E

(a)

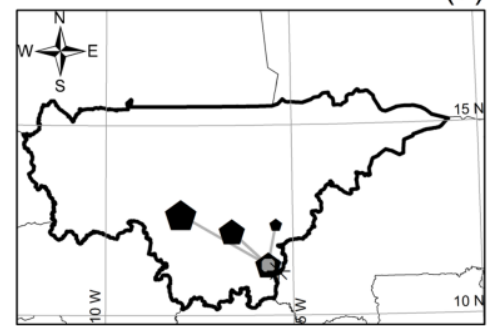

(b)

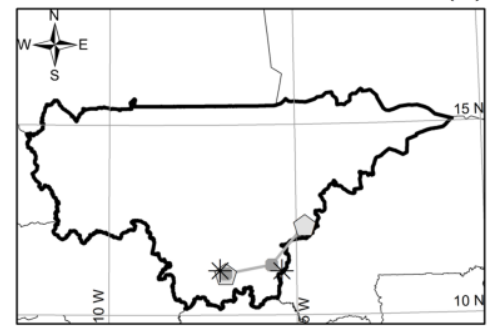

(c)

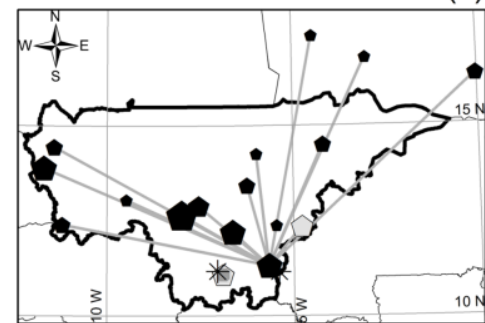

$\begin{array}{llll}0 & 150 & 300 \quad 600 \\ \end{array}$

Figure 7 - Spatial layout of the optimal Jatropha-based electricity value chains for three different scenarios (a) current scenario; (b) future scenario with off-grid contribution; and c) future scenario with on-grid contribution). The left column contains the results of the base case while the centre and right columns show the results of the sensitivity analysis to a cap of 5000 ha of Jatropha plantations in each selected cultivation area and the exclusion of LUC emissions from the model parameters. Selected cultivation sites are marked with a star, storage sites with a circle, and the placement of generators with a light pentagon. The thermal power plants fed by the value chain are indicated with dark pentagons of different sizes proportional to the power plant's capacity. Transport links between sites are represented by grey lines.

\subsection{Sensitivity analysis}

With a 5000 ha limit on the plantation size in each selected cultivation area, the complexity of the value chain increases, with more cultivation sites being selected: 3, 18 and 22 sites in scenarios 1,2 and 3, respectively (figure 7, central column). In relation to the base case, the total area required by plantations decreases in Scenario 1 to $138 \mathrm{~km}^{2}$ and increases in scenarios 2 and 3 to 801 and $1092 \mathrm{~km}^{2}$. Because there are more cultivation areas, the number of cercles receiving generators also increases to 5 in Scenario 2 and to 4 in Scenario 3. With the constraint on the plantation area the GWP efficiency worsens by $12 \%, 60 \%$ and $84 \%$ scenarios 1, 2 and 3 respectively, underlined by LUC emissions rising 19-105\% (table 3). 
In case LUC emissions are excluded, the total GWP of the optimal value chain decreases $86 \%$ (table 2). These percentages are slightly higher than the contribution of LUC emissions to the GWP because the geographical layout of the value chain in this sensitivity analysis is readjusted (figure 7, right column), slightly lowering transportation emissions. In all scenarios there are two selected cultivation areas, storage sites and electrified cercles, where rural electrification is foreseen (Scenarios 2 and 3). These remain in the far south of the study area. The yield is higher than in the baseline scenarios (above $2 \mathrm{t} \mathrm{ha}^{-1}$ ). The required land area ranges from 103 $\mathrm{km}^{2}$ to $648 \mathrm{~km}^{2}$, which is $2-16 \%$ of the area of the selected cells.

Table 3 - Absolute GWP of the value chain $\left(\mathrm{Gg} \mathrm{y}^{-1}\right.$ of $\left.\mathrm{CO}_{2} \mathrm{eq}\right)$ if there is a limit of 5000 ha of Jatropha plantations per cultivation and if LUC emissions are excluded.

\begin{tabular}{llll}
\hline & $\begin{array}{l}\text { Scenario 1 } \\
\text { (current) }\end{array}$ & $\begin{array}{l}\text { Scenario 2 } \\
\text { (future off-grid) }\end{array}$ & $\begin{array}{l}\text { Scenario 3 } \\
\text { (future off-grid and on-grid) }\end{array}$ \\
\hline 5000 ha limit & 25.4 & 157 & 255 \\
Exclusion of LUC emissions & 3.23 & 13.6 & 19.5 \\
\hline
\end{tabular}

\subsection{Replaced land cover types}

Figure 8 shows the combination of the selected cultivation areas with the land cover classification of the area. Cropland is the predominant land cover in the areas selected in the base case as in the sensitivity analysis cases. The lowest overlap with cropland occurs when a 5000 ha extension limit is considered (82-84\% overlap) and the highest is in the base case $(94 \%)$ overlap.

\section{Discussion}

\subsection{The optimal value chains}

The optimal set-ups (figure 7) and the GWP efficiency (table 3) both suggest that using Jatropha oil for rural electrification is less advantageous in terms of GWP than replacing fossil fuels with Jatropha oil in large thermal power plants. However, this result must be seen in the light that the efficiency of on-grid electrification does not consider distribution losses and any necessary technological adaptations to Jatropha oil use. If data were available, these factors could be included and might sway the GWP efficiency towards rural electrification. However, thorough sensitivity analyses are required to define the likely level and direction of impact on the optimal value chain set-up and the GWP efficiency.

The GWP of the optimal value chains is in line with a Jatropha LCA performed in Mali: $1.73 \mathrm{~kg} \mathrm{kWh}^{-1}$ of $\mathrm{CO}_{2}$ eq upon the conversion of cropland and $5.14 \mathrm{~kg} \mathrm{kWh}^{-1}$ of $\mathrm{CO}_{2}$ eq of fallow, with $58-86 \%$ of emissions originating from LUC [42]. These discrepancies can be due to the fact that the aforementioned LCAs gauged the GWP of sub-optimal production systems in terms of cultivation management, harvest success and downstream efficiency, which are commonplace in Jatropha bioenergy projects [10, 33]. In contrast, a value chain laid out and dimensioned using OPTIMASS inherently results in the lowest possible GWP and the best GWP-to-yield relation taking into account the user-defined constraints and definitions. This emphasizes the idea that there is room for improvement of existing Jatropha initiatives on what concerns their mitigation potential and this can be explored by the approach of combining spatially explicit value chain optimization and LCA data. The ex-ante modeling can dimension and locate the technologies required to achieve a certain objective, whilst showing promise of better land allocation for energy crop cultivation. Improving the reliability of the selection of 
cultivation sites can also be foreseen by running OPTIMASS with a more comprehensive set of parameters and objective functions that optimize for socio-economic and other environmental issues. Still, additional risks to productivity inherent to investments in Jatropha remain valid, as will be discussed in this text later on.
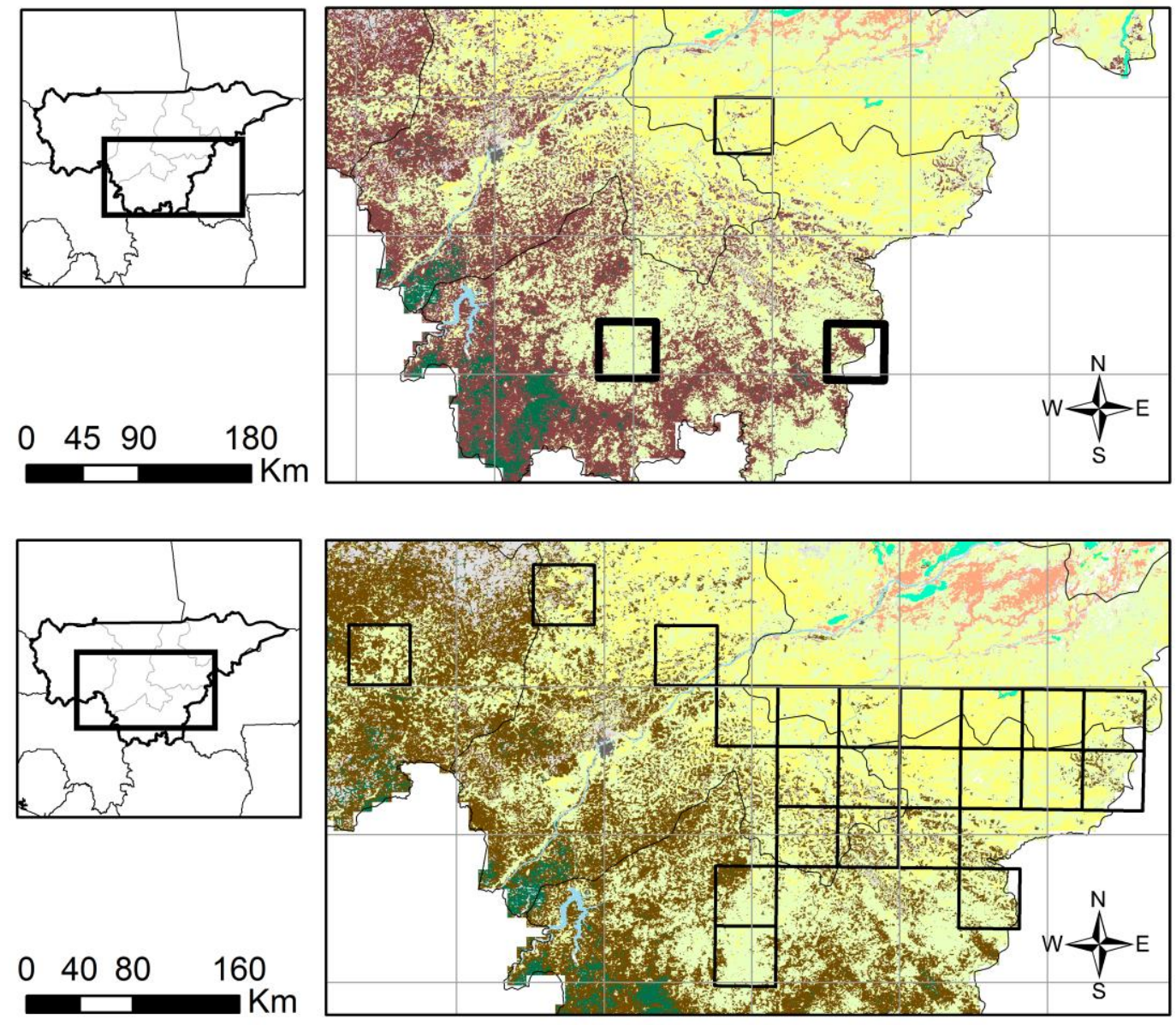

\section{Legend}

Water bodies

Cropland

Mosaic cropland/Vegetation

Forest

Mosaic forest or shrubland/grassland

$\square$ Selected cultivation cell (with LUC)

Selected cultivation cell (without LUC)

\section{Shrubland}

Herbaceous vegetation Bare or sparce vegetation

Regularly flooded/waterlogged area Urban area

\section{Province boundary}

Figure 8 - Land cover types found in the selected cells for Jatropha cultivation in the base case (thin line, top map), without LUC emissions (thick line, top map) and with a 5000 ha limit (bottom map).

Globally, the GWP of electricity generation from fossil fuel $\left(0.27 \mathrm{~kg} \mathrm{kWh}^{-1}\right.$ of $\mathrm{CO}_{2}$ eq [37]) is 4.5-6 times less than the GWP efficiency of the optimal Jatropha value chains. If the substitution of fertilizers with Jatropha byproducts is taken into account, then the GWP optimal value chains is 60-66\% lower than if the same amount of energy was provided by fossil fuels. Hence, harnessing the entirety of the Jatropha value chain is crucial do make it GWP competitive relative to fossil fuels. 
The production of bioenergy carriers based on Jatropha cropping is not present in mainstream LCA databases such as ecoinvent ${ }^{\circledR}$ (Swiss Centre for Life Cycle Inventories, Switzerland) and ELCD (JRC, Italy). Hence, processes leading to Jatropha-based bioenergy must be modeled from cradle to gate. It is possible, however, to use unit processes present in ecoinvent ${ }^{\circledR}$ as inputs to the system, being chemical products or transport. In this paper, the LCI was consistently done in this manner. Foreground data on system layout and quantification was site-specific, while background data on intervening unit processes was mostly retrieved from ecoinvent ${ }^{\circledR}$ (and tabled values in GREET 2013 and IPCC reports for direct emission factors).

Despite its increasing coverage of country-specific processes, ecoinvent ${ }^{\circledR}$ still does not cover many regions of the world such as most of Africa and South America. For this reason, the practitioner is opting out of a more specific geographical coverage. While this may not be important for products that are imported to the country at hand, it can be so for other inputs such as electricity and transport.

When building the LCI and selecting emission factors of Jatropha-based bioenergy production in Mali, we were mindful of these limitations and sought to include local data when possible. However, products such as chemicals (e.g. fertilizers and transesterification), machinery and fossil fuels were retrieved from ecoinvent ${ }^{\circledR}$. When available, global averaged data sets were selected for processes and emission factors so as to distance the LCI from European conditions, predominant in ecoinvent ${ }^{\circledR}$. Direct emission factors were, however, generalized from sources that are not specific for West African conditions. An uncertainty analysis (such as Monte Carlo) could be performed to estimate the uncertainty related to the use of non-local data for the background processes. However, the processes whose emissions were estimated from ecoinvent were expected to have a small contribution to the overall emissions of the functional unit and the inputs to the supply chain in question are unlikely to be produced in Mali, but rather being imported. As these background processes are likely to be linked to processes not occurring in Mali in reality, an uncertainty analysis would typically yield little signal. Furthermore, a Monte Carlo uncertainty analysis would use the distribution data available for the European or Global average background data as available in EcoInvent, and would therefore not assess the uncertainty related to specific differences with Mali.

\subsection{Land use change emissions}

Since direct LUC has been indicated as a crucial factor in the GHG emission profile of biofuels [43], this optimization exercise aimed at allocating land for cultivation, so as to minimize $\mathrm{CO}_{2}$ emissions from land clearing and soil disturbance. The method, described in this paper, to estimate spatially allocated LUC emissions can in fact be implemented to any other optimization model capable of spatial analysis. Alternatively, it can be used as a standalone input for GWP quantification methods, such as Annual Based Carbon (ABC) accounting [44] or LCA.

Given that OPTIMASS seeks the best compromise between yield and GHG emissions to select the cultivation areas (figure 8) in order to design a value chain with the lowest possible GWP, the impact of LUC in the GWP can differ in non-optimal value chains with non-optimal LUCE/yield ratios. When seen from the perspective of yield, rather in function of area, zones with lower yields - corresponding to drier parts of the country - are less desirable even in terms of $\mathrm{CO}_{2}$ emissions. Wetter and more productive areas can present a lower emission/yield 
ratio, in contrast with the idea that converting non-marginal land to Jatropha has severe consequences to its biofuels' GWP (figure 8). Still, aside from protected areas, the value of previous land use is not considered in this study, and in some areas lower GWP may be a trade-off with other ecosystem services and with increased land pressure (figure 8).

The estimation of the biomass carbon content $\left(\mathrm{t} \mathrm{ha}^{-1}\right)$ was calculated from the available Global Biomass Carbon

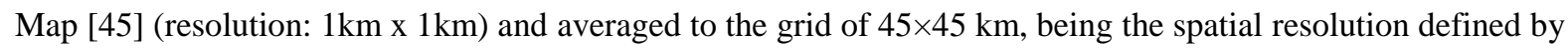
the computational power (Supplementary material). Also, the calculation of the SOC stocks is quite heavily reliant on assumptions and extrapolations (Supplementary material). As such, rather than a rigorous reference for the carbon balance of Jatropha plantations, the maps in figure 8 provide a screening of the predictable impact on soil and biomass carbon stocks if Jatropha-projects are implemented. This suggests preferential areas but ought to be validated with field measurements and assessments prior to the selection of particular sites to define land quality, climate, topography, social context, access to transport, neighboring land use, etc. Based on these insights, the conflict with other valuable ecosystem services can also be avoided.

The facts that the SOC under Jatropha is empirically modeled and that the modeling is based on data extrapolations from other sites and plantations of several ages is due to limited data availability. This problem of lack of chronosequences of SOC under Jatropha plantations, which prompted the use of a soil carbon dynamics model to predict the evolution of SOC throughout time, has been reported before [46, 47]. Most plantations are relatively young and, when measured, SOC shows little or no correlation with tree age. Baumert (2014) [46] suggests that there is accumulation of carbon in hedges and young plantations, but her long-term estimations point towards carbon losses, as we also conclude in this study. In an attempt to fill this knowledge gap with a comprehensive empirical model, RothC was chosen due to its relatively limited data requirements, to match low data availability, and because it has been shown to accurately predict SOC dynamics in the Sahel [48, 49]. However, the model shows serious limitations like ignoring mechanical soil disturbance, which emphasizes the need for field validation of the LUC emissions.

Further uncertainty arises from the fact that Jatropha is still a semi-domesticated crop from the agronomical point of view, with much work still ongoing in terms of selecting plant varieties and fine-tuning cultivation practices. Termites, pests and the unstable climate of the Sahelian region are also threats to attaining the yields purported by the productivity map [29]. This does not necessarily mean that lower yields should be expected [50], but it serves to remind that the choice of a low LUCE/yield location is not the sole factor playing in the GWP of Jatropha cultivation.

Although an indirect LUC (iLUC) emission modeling was not in the scope of this study, we acknowledge that it is another aspect of land occupation that ought to be evaluated. Achten and Verchot (2011) [51] report on the probable magnitude of iLUC impact from Jatropha plantations in Ghana, but only in the case that agricultural crops are displaced, which would be the case for the optimal value chain. If we assume similar conditions between the two countries, we could expect an additional emission of $11 \mathrm{t} \mathrm{ha}^{-1}$ of $\mathrm{CO}_{2}$ upon the establishment of Jatropha in cropland [51]. The conflict with food production can be foreseen in the optimization procedure by adding a constraint in OPTIMASS denying the occupation of cropland.

Since our approach is forced to simplifications due to lack of both computing power as of reliable data for the study region, it has ample room for improvement. The conflict with computing power comes from the trait 
inherent to integer programming: the size of the model and the time that it takes to solve the problem is exponential to its number of decision variables [52]. A first step is to increase hardware capacity so as to match the requirements of OPTIMASS when dealing with more potential cultivation sites and, therefore, decrease the size of land units from $45 \times 45 \mathrm{~km}$, gaining precision in the location of cultivation areas. Secondly, because the independent modeling of SOC is very time consuming, it is unpractical to use the current approach to other crops or countries or in a multi-crop and multi-product optimization as OPTIMASS has previously performed [17]. This can be solved by integrating RothC, or another existing SOC model, into the GIS module in order to automatize the SOC modeling per area. The protocol described in the Supplementary Material is enabled for this possibility since all allocation steps are related to readily available variables, such as climate and soil properties.

\subsection{By-product handling}

In a standard LCA-based GWP calculation, the impact allotted to by-products must be handled either through allocation or system boundary expansion/substitution. Besides oil, the value chain of Jatropha generates organic residues (seed cake, discarded fruit parts and oil sediment) with functional and economical value. Including them in the GWP calculations would either dislocate a share of the impact onto them or created a credit to the system by the avoided production of their functional equivalents. Avoided production of fertilizers by the substitution with seed cake and fruit parts (according to the mass ratios and nutrient contents reported in [53]) would result in a decrease of $93 \%$ in the GWP of the baseline optimal value chain.

\section{Conclusions}

The combination of optimization modeling with LCIA and LUC metrics is here demonstrated to be suitable to plan bioenergy endeavors (Objective 1). Being adaptable to multiple crops, final products, potential sites and operations and optimization objectives (whether or not combined), OPTIMASS can be used to screen the national and regional potential to implement bioenergy policies or to plan for specific goals. In general, the presented methodology shifts the focus from assessing the consequences and potentials of the projected use of a resource to a definition on if and how the resource can be used for optimal effect and meeting an anticipated potential (Objective 3).

This study also shows that in a country with very low electricity consumption rates and low electrification rates, soundly planned bioenergy value chains can make a difference in reducing the dependence from fossil fuels and electrifying off-grid, rural households (Objective 2). Even in the face of one of the fastest growing electricity demand rates in the world, our results suggest that a Jatropha approach could realize those goals in a more sustainable manner compared to fossil fuels. However, harnessing the entirety of the Jatropha value chain is crucial to make it GWP competitive relative to these fossil fuels (Objective 3).

Finally, the results demonstrate that the location of plantations is crucial to attain low LUC-related emissions and viable yields (Objective 3). This clarification is made possible by expressing the impact of LUC in function of yield rather than land area. Simultaneously, OPTIMASS gauges the required equipment and its capacity and logistic requirements for the value chain to work. This valuable information covers aspects which have been seen to compromise projects for Jatropha-based electrification in Mali, such as the lack of infrastructure. 
Joana Almeida holds the doctoral grant number SFRH/BD/72015/2010 from the Portuguese Foundation for Science and Technology (FCT). Annelies de Meyer is funded by a doctoral grant of the Agency for Innovation by Science and Technology (IWT) in Flanders, Belgium. This study was performed in the framework of the KLIMOS Acropolis project on sustainable development (VLIR/ARES/Belgian Development Cooperation). The authors wish to thank Koenraad Van Meerbeek for his contribution to the cluster analysis.

\section{References}

[1] Coulibaly A, Bonfigloli A. Renewable Energy in Mali: Achievements, Challenges and Opportunities. Bamako: National Directorate of Energy and Africa Development Bank; 2012.

[2] Achten WMJ, Maes WH, Aerts R, Verchot LV, Trabucco A, Mathijs E, et al. Jatropha: from global hype to local opportunity. J. Arid Environ. 2010;74:164-5.

[3] Brittaine R, Lutaladio N. Jatropha: a smallholder bioenergy crop. The Potential for pro-poor development. Integrated Crop Management. Rome: Food and Agriculture Organization; 2010.

[4] Fairless D. Biofuel: The little shrub that could - maybe. Nature. 2007;499:652-5.

[5] Muys B, Norgrove L, Alamirew T, Birech R, Chirinian E, Delelegn Y, et al. Integrating mitigation and adaptation into development: the case of Jatropha curcas in sub-Saharan Africa. GCB Bioenergy. 2014;6(3):16971.

[6] van Eijck J, Romijn H, Balkema A, Faaij A. Global experience with jatropha cultivation for bioenergy: An assessment of socio-economic and environmental aspects. Renew. Sustainable Energy Rev. 2014;32(0):869-89. [7] Schut M, van Paassen A, Leeuwis C, Bos S, Leonardo W, Lerner A. Space for innovation for sustainable community-based biofuel production and use: Lessons learned for policy from Nhambita community, Mozambique. Energy Policy. 2011;39(9):5116-28.

[8] Skutch M, de los Rios E, Solis S, Riegelhaupt E, Hinojosa D, Gerfert S, et al. Jatropha in Mexico: Environmental and Social Impacts of an Incipient Biofuel Program. Ecol. Soc. 2012;16(4):11.

[9] Achten W, Sharma N, Muys B, Mathijs E, Vantomme P. Opportunities and Constraints of Promoting New Tree Crops: Lessons Learned from Jatropha. Sustainability. 2014;6(6):3213-31.

[10] Favretto N, Stringer LC, Dougill AJ. Unpacking livelihood challenges and opportunities in energy crop cultivation: perspectives on Jatropha curcas projects in Mali. Geogr. J. 2014; 180(4):365-376.

[11] Fargione J, Hill J, Tilman D, Polasky S, Hawthorne P. Land Clearing and the Biofuel Carbon Debt. Science. 2008;319(5867):1235-8.

[12] Kleiner K. The backlash against biofuels. Nature Clim. Change. 2008;2:9-11.

[13] Panichelli L, Gnansounou E. GIS-based approach for defining bioenergy facilities location: A case study in Northern Spain based on marginal delivery costs and resources competition between facilities. Biomass Bioenergy. 2008;32(4):289-300.

[14] Natarajan K, Leduc S, Pelkonen P, Tomppo E, Dotzauer E. Optimal Locations for Methanol and CHP Production in Eastern Finland. Bionerg. Res. 2012;5(2):412-23.

[15] Tittmann PW, Parker NC, Hart QJ, Jenkins BM. A spatially explicit techno-economic model of bioenergy and biofuels production in California. J. Transp. Geogr. 2010;18(6):715-28.

[16] De Meyer A, Cattrysse D, Van Orshoven J. Methods to optimise the design and management of biomassfor-bioenergy supply chains: a review. Renew. Sustainable Energy Rev. 2014;31:657-70.

[17] De Meyer A, Cattrysse D, Van Orshoven J. A mixed integer linear programming model for the strategic optimisation of biomass-for-bioenergy supply chains. EU BC\& E Proceedings 2013 - Setting the course for a biobased economy 21th European Biomass Conference \& Exhibition Copenhagen, Denmark, June 3-7 20132013. p. 52-63.

[18] De Meyer A, Almeida J, Achten WMJ, Muys B, Cattrysse D, Van Orshoven J. Incorporating life cycle thinking in a mathematical model to optimize strategic decisions in biomass-for-bioenergy supply chains. Fulfilling LCA's Promise - Proceedings from the LCA XIII International Conference, October 1-3 2013, Orlando, FL, United States 2013. p. 24-33.

[19] Mele FD, Kostin AM, Guillén-Gosálbez G, Jiménez L. Multiobjective Model for More Sustainable Fuel Supply Chains. A Case Study of the Sugar Cane Industry in Argentina. Ind. Eng. Chem. Res. 2011;50(9):493958.

[20] You F, Wang B. Life Cycle Optimization of Biomass-to-Liquid Supply Chains with Distributed-Centralized Processing Networks. Ind. Eng. Chem. Res. 2011;50(17):10102-27.

[21] De Meyer A, Cattrysse D, Van Orshoven J. A generic mathematical model to optimise strategic decisions in biomass-for-bioenergy supply chains (OPTIMASS). Eur. J. Oper. Res. in press. 
[22] Čuček L, Klemeš JJ, Varbanov PS, Kravanja Z. Life cycle assessment and multi-criteria optimization of regional biomass and bioenergy supply chains. Chemical Engineering Transactions 2011; 25: 575-80.

[23] Pieragostini C, Mussati MC, Aguirre, P. On process optimization considering LCA methodology. Journal of Environmental Management 2012; 96: 43-54.

[24] Santibañez-Aguilar JE, González-Campos JB, Ponce-Ortega JM, Serna-González M, El-Halwagi MM. Optimal planning and site selection for distributed multiproduct biorefineries involving economic, environmental and social objectives. Journal of Cleaner Production 2014; 65: 270-94.

[25] Steubing B, Mutel C, Suter F, Hellweg S. Streamlining scenario analysis and optimization of key choices in value chains using a modular LCA approach. Int J Life Cycle Assess. 2016; 21(4): 510-22.

[26] UNSD. 2013 World Statistics Pocketbook - Country Profile: Mali. Available at: http://data.un.org/CountryProfile.aspx?crName=MALI. New York, USA: United Nations Statistics Division; 2014.

[27] CIA. The world factbook. Available at: www.cia.gov/library/publications/the-world-factbook. Central Inteligence Agency; 2014.

[28] Venugopal V. Open data for Mali. Available at: http://mali.opendataforafrica.org. Tunis-Belvedère, Tunisia: African Development Bank Group; 2014.

[29] Trabucco A, Achten WMJ, Bowe C, Aerts R, Orshoven JV, Norgrove L, et al. Global mapping of Jatropha curcas yield based on response of fitness to present and future climate. GCB Bioenergy. 2010;2(3):139-51.

[30] Openshow, K. A review of Jatropha curcas: an oil plant of unfulfilled promise. Biomass Bioenergy. 2000; 19(1): 1-15.

[31] Achten WMJ, Verchot L, Franken YJ, Mathijs E, Singh VP, Aerts R, et al. Jatropha bio-diesel production and use. Biomass Bioenergy. 2008;32(12):1063-84.

[32] Almeida J, Achten WMJ, Duarte MP, Mendes B, Muys B. Benchmarking the Environmental Performance of the Jatropha Biodiesel System through a Generic Life Cycle Assessment. Environ. Sci. Technol. 2011;45(12):5447-53.

[33] Almeida J, Moonen PCJ, Soto I, Achten WMJ, Muys B. Effect of farming system and yield in the life cycle assessment of Jatropha-based bioenergy in Mali. Energy Sustain. Dev. 2014;23:258-65.

[34] Soltic, P., Edenhauser, D., Thurnheer, T., Schreiber, D., and Sankowski, A. Experimental investigation of mineral diesel fuel, GTL fuel, RME and neat soybean and rapeseed oil combustion in a heavy duty on-road engine with exhaust gas aftertreatment. Fuel 2009;88:1-8.

[35] Goedkoop M, Heijungs R, Huijbregts M, De Schryver A, Struijs J, van Zelm R. ReCiPe 2008, A life cycle impact assessment method which comprises harmonised category indicators at the midpoint and the endpoint level; First edition Report I: Characterisation. Available at: http://www.lcia-recipe.net. 2012.

[36] IPCC. National Greenhouse Gas Inventories vol. 4: Agriculture, Forestry and Other Land Use Japan: IGES; 2006.

[37] Argonne National Laboratory. GREET 2013 model. 2013. Available at: https://greet.es.anl.gov/publicationgreet-model.

[38] Romijn HA. Land clearing and greenhouse gas emissions from Jatropha biofuels on African Miombo Woodlands. Energy Policy. 2011;39(10):5751-62.

[39] Quinn L, Straker K, Guo J, Kim S, Thapa S, Kling G, et al. Stress-Tolerant Feedstocks for Sustainable Bioenergy Production on Marginal Land. Bioenerg. Res. 2015:1-20.

[40] EC, JRC. Global Land Cover 2000 database. Available at: http://gem.jrc.ec.europa.eu/products/glc2000/glc2000.php. 2003.

[41] DESA. World Population Prospects: The 2012 Revision. Available at: http://esa.un.org/unpd/wpp/index.htm. New York, USA: United Nations Department of Economic and Social Affairs; 2014.

[42] Almeida J, Degerickx J, Achten WMJ, Muys B. Land use change related $\mathrm{CO}_{2}$ emissions in the LCA of biofuel-based electrification in Mali. Book of Abstracts of Ecobalance 2014, 28-30 October, Tsukuba, Japan. Tsukuba, Japan: Life Cycle Assessment Society of Japan; 2014.

[43] Njakou Djomo S, Ceulemans R. A comparative analysis of the carbon intensity of biofuels caused by land use changes. GCB Bioenergy. 2012;4(4):392-407.

[44] DeCicco J. Biofuels and carbon management. Clim. Chang. 2012;111(3):627-40.

[45] Ruesch A, Gibbs HK. New IPCC Tier-1 Global Biomass Carbon Map For the Year 2000. Available online from the Carbon Dioxide Information Analysis Center (http://cdiac.ornl.gov), Oak Ridge National Laboratory, Oak Ridge, Tennessee. 2008.

[46] Baumert S. Life cycle assessment of carbon and energy balances in Jatropha production systems of Burkina Faso. Bonn: University of Bonn; 2014.

[47] Degerickx J, Almeida J, Moonen PCJ, Vervoort L, Muys B, Achten WMJ. Impact of land use change to Jatropha bioenergy plantations on biomass and soil carbon stocks: a field study in Mali. GCB Bioenergy. accepted. 
[48] Takimoto A, Nair V, Nair PKR. Contribution of trees to soil carbon sequestration under agroforestry systems in the West African Sahel. Agrofor. Syst. 2009;76(1):11-25. [49] Nakamura S, Hayashi K, Omae H, Ramadjita T, Dougbedji F, Shinjo H, et al. Validation of soil organic carbon dynamics model in the semi-arid tropics in Niger, West Africa. Nutri. Cycl. Agroecosyst. 2011;89(3):375-85. [50] Soto I, Achten WMJ, Moonen PCJ, Trabucco A, Mereu S, Negussie A, et al. Impacts of tropical land use conversion to Jatropha on rural livelihoods and ecosystem services in Mali - Jatrophability Mali final report. 2013.

[51] Achten WMJ, Verchot LV. Implications of Biodiesel-Induced Land-Use Changes for $\mathrm{CO}_{2}$ Emissions: Case Studies in Tropical America, Africa, and Southeast Asia. Ecol. Soc. 2011;16(4):14.

[52] Scharge L. Optimization modeling with LINGO. Chicago: LINDO Systems Inc.; 2012.

[53] Contran N, Chessa L, Lubino M, Bellavite D, Roggero PP, Enne G. State-of-the-art of the Jatropha curcas productive chain: From sowing to biodiesel and by-products. Ind. Crops Prod. 2013;42(0):202-15. 